\title{
REGENERATIVE DISCOURSES \\ IN CONTEMPORARY AFRO-BRAZILIAN WOMEN WRITERS
}

Niyi Afolabi*

\begin{abstract}
Drawing on James Scott's idea of "hidden transcripts" in Domination and the Arts of Resistance, this study theorizes on progressive hypothetical discursive sites as moving from the continuum of the harsh slave master to the site of the free black among friends and family. Instead of the fear of articulation or the need for masking that operates in the public transcript frame, the alternating hidden transcript frame suggests a less explicit fear of articulation in the face of oppression. In addition to highlighting recent works on issues of gender, identity, and citizenship in Brazil, this essay argues that a new wave of regenerative discourses is emerging among Afro-Brazilian women writers however few and far between. These works demonstrate conscious regenerative acts from the viewpoints of rejection of victimhood.
\end{abstract}

KEYWORDS: Afro-Brazilian women writers; Hidden transcripts; Resistance.

This essay grows out of an on-going reflection on the subject of "hidden transcripts"1 within the framework of critical and creative responses to domination in both public and private spaces. I use "scripts" here to represent verbal and visual expressions that define not only the code embedded in the message of the coder but also the infinite possibilities of meaning engendered by the very act of articulation or performance as a form of coding whether public

\footnotetext{
* PhD. Teaches Luso-Brazilian, Yoruba, and African Diaspora Studies at the University of Texas at Austin-in the Department of African and African Diaspora Studies Department. afolabi@austin.utexas.edu.

${ }^{1}$ For a detailed discussion of hidden transcripts, see James Scott, Domination and the Arts of Resistance (New Haven: Yale University Press, 1990), 191-192; 202-227.
} 
or private. Scripting needs not be coded to be laden with covert meanings — the act of activating the voice through signs or scripts translates a consciousness of renunciation of silence. Far from being the "weapon of the weak," scripting, double-voicing, double-talking, masking, among other veils of protestation, respond to respective contextual power relations. James Scott in Domination and the Arts of Resistance theorizes on progressive hypothetical discursive sites as moving from the continuum of the harsh slave master to the site of the free black among friends and family. Instead of the fear of articulation or the need for masking that operates in the public transcript frame, the alternating hidden transcript frame suggests a less explicit fear of articulation in the face of oppression. In addition to highlighting recent works on issues of gender, identity, and citizenship in Brazil, this essay argues that a new wave of regenerative discourses is emerging among female writers however few and far between. As specific case studies, I focus primarily on the recent works of Elisa Lucinda, Jussara Santos, and Conceição Evaristo which demonstrate conscious regenerative acts from the viewpoints of victimhood.

In the field of Afro-Latin American studies, broadly defined, intellectual critical labor as well as its corresponding creative production continues to be marred by a subtle divide between canonicity and marginality, between gendered focus and racial concern, between national and transnational dialogue, and ultimately, between colonized and decolonized paradigms. In view of its ability to synergize and challenge these artificially compartmentalized units, Dawn Duke's Literary Passion, Ideological Commitment, should be welcome. A lasting oeuvre of critical initiation into the hitherto colonized world of criticism in which hegemonic critical voices have not only dominated critical responses to works by Afro-Cuban and Afro-Brazilian women writers, but have often marginalized and resisted alternative counter-hegemonic alternative such as that of Dawn Duke. The fact that she was able to place this with a university press alone is already an accomplishment for visibility. Indeed, in the reality of limited critical outlets for what has been termed "marginal" literature, many seminal works end up in ambivalent academic and trade presses due to what publishers call "marketing considerations." For the world of Afro-Cuban and Afro- 
Brazilian women can only be marketable if the subjects are "objectified" as in samba, carnival, and other stereotypical representations or roles. The challenging feat of contesting colonial, sexist, and racist criticism has a far reaching impact than could be measured within the immediate accomplishments of this monograph. Ultimately, as her sub-titles captures in "toward a legacy," this work is only the beginning of a much needed focused, scholarly, and un-apologetic treatise on Afro-Latin American and Afro-Caribbean women writers.

Duke's thesis can be summed up in the following mix of cogent arguments that not only historicize but provide the framework for a better understanding of the import of these writers to female self-empowerment and ideological commitment: (i) That due to the legacy of colonialism, patriarchy, and slavery, women were historically locked into stereotypical images that are also predicated on racial and gendered hierarchies. (ii) That following ideological consciousness, women have shifted location from written subjects to writing subjects in the sense of writing themselves as opposed to being written by the colonized and enslaving gaze. (iii) That not only did women have had to deal with negative stereotypes from racialized power but also in recent racial discourse, they also have to challenge class and gender relations as limitations are often placed on female voices thus doubly marginalizing them. (iv) That there is a symbiotic relationship between political context and literary production since creative imagination is nourished the socio-political contexts. (v) Finally, that the main themes of the writers examined range from issues of female strength, the inner self, African historical, cultural, and spiritual heritage, and woman-centered aesthetics.

The five chapters are systematically designed "against the grain" in order to lead from historical, theoretical, to practical analysis that takes into consideration the political nature of writing. As Duke cogently asserts: "Writing results in the inclusion of the AfroLatin American female perspective that questions the parameters and cultural philosophical descriptions of racial and ethnic identity that are in place. Her literature becomes a counter discourse that confirms the distance covered from initial historical images and establishes her discourse as a legitimate representation of Latin American identity and subjectivity 
(20)." Chapter 1 discusses the imposed portrayals of Afro-Latin American women by male writers as a pretext to engage the transformed female portrayals by women writers in the subsequent chapter. Chapter 2 enlists and analyzes the first generation of "transforming female voices" such as the Brazilian writer, Maria Firmina dos Reis (1825-1917), and the Cuban writer, Maria Damasa Jova Baró (1890-1940) as a model for what Duke calls “black female subjectivity and agency." Chapter 3 historicizes the emergence of literary magazines such as La Igualdad (Cuba) and Menelick (Brazil), and later on the aesthetic movement of Afrocubanismo and Quilombhoje as the foundations for black consciousness militancy which provided alternatives for black female inclusion. Chapters 4 and 5 address female strength and sexuality through the larger prism of such movements of Negritude, Africanness, and diasporic ethnic identity. In her discussion of the remaining selected AfroCuban and Afro-Brazilian women writers, namely Esmeralda Ribeiro, Miriam Alves, Conceição Evaristo, Alzira Rufino, and Geni Guimarães (Brazil) and Georgina Herrera, Nancy Morejón, and Excilia Saldana (Cuba), Duke not only evokes female strength in their works, she also associates their treatment of Yoruba female deities such as Oxum and Iemanjá as an agency of female empowerment in the works of the writers.

In sum, Duke has presented us with a provocative and seminal work in Literary Passion, Ideological Commitment, that sets out to revise and re-envision the Afro-Latin American woman through ideological commitment and gendered agency of empowerment. Far from being a modest contribution to the field of Afro-Latin American studies, it promises to encourage further independent studies on women that no longer need to hide under the pretexts of race, class, and cultural studies.

In line with this "winning attitude" formulated in Dawn Duke's work is a female and persistent Afro-Brazilian voice in the person of Elisa Lucinda. Contrary to the "oppressed" self-image and attempt to recuperate the assaulted black body over many centuries as in the works of Miriam Alves, Conceição Evaristo, Esmeralda Ribeiro, and Sônia Fátima da Conceição among others, Lucinda does not set out to combat what Zillah Einseinstein calls 
"patriarchal capitalism"2 which specializes in racial, sexual, and class oppression. Rather, she states that "we need to have an attitude of Afro-Brazilians who take charge of their destiny and who have a secure political posture." 3 While Lucinda speaks for some Brazilians who claim that "race" or "color" has nothing to do with success, she is definitely at odds with many AfroBrazilians who feel she had a privileged background and is only reaching out to middle-class Brazilians not the masses. A bi-racial with green eyes, Lucinda's blend of poetry with theatrical performance is rare indeed — she captures the audience (black or white) with the same love for words, the passion to perform their message, and a certain natural bonding with her audience. According to her, she learnt to "speak from the heart" very early when her mother, Divalda Campos Gomes, took her to poetry lessons with her teacher, Maria Helena Salles de Miranda. For Lucinda, the influence of the teacher who introduced her to the poetry of Fernando Pessoa, Adélie Prado, and Cecília Meireles, was fundamental. Lucinda's success lies in her productivity and her penchant for racial non-alignment or hybridity. With confidence, she prophesies her own reign and recognition when at the end of her own preface to O Semelhante [The Similar One], she states: "red carpets are just around the corner."

The "red carpet" has long be in the making for Lucinda since her collaboration in the anthology Mulheres (In) Versos (1990) and other single-authored collections such as Aviso da Lua Que Mesntrua (1992) and Sósias dos Sonhos (1994). Similar to the contradictory "essence" which she embodies in life and work, the opening poem to O Semelhante, "O Poema do Semelhante" [The Poem of the Similar One] sets out to establish the "sameness" of all beings and gives thanks to God of equality for allowing her to produce such "poetry of destiny," taking away its individual robe and enrobing with a just and greater individual. "Possessor of many souls" as she describes herself, she breaks into enumerating common characteristics of all humans as if these negate social realities that make it even impossible to exercise these feelings without

${ }^{2}$ Cited in Luiza Lobo, "Corpo Negro: A Auto-Imagem Agredida," Crítica Sem Juízo (Rio de Janeiro: Francisco Alves, 1993), 239.

${ }^{3}$ See Rita Homero, "Elisa Lucinda Abre o Verso,” Raça 2.10 (1997): 46-49. 
the feeling of difference, alienation, and oppression: "todo mundo beija / todo mundo almeja / todo mundo deseja / todo mundo chora" (18) [everyone kisses / everyone yearns / everyone desires / everyone cries]. Lucinda's contradiction sets in when she thanks God for making her equal in order for her to prove the happy feeling that she is "equal to everyone." If in fact she is equal to everyone, there should be no need to "prove" it to anyone. Beyond contradictions, there is also a sense of hypocrisy, one that is equally betrayed in the last stanza: "Não fosse a inteligência / da semelhança / seria só meu o meu amor / seria só minha minha dor" (19) [If not for the logic / of sameness / my love would only be just mine / my pain would just be mine]. The fact of the matter is that there is no logic in everyone sharing the other's love and pain for these are feelings that come to light in varying degrees according to circumstances. To lock everyone into the same box of feelings is illogical. Some slave owners argued that they were expressing love to their slaves by keeping them captive since they could not fend for themselves even after abolition. Some slaves were also made to believe that they deserved the pain they were suffering due to transgressions of the past. The citadel of brainwashing seems complete with the addition of Lucinda's lyricism, which despite its artistic merits, lacks any sense of consciousness for the oppressed. Equality is in the eyes of the beholder and for Lucinda, this poem is a thesis on "racial democracy," a claim that is both ridiculous and baffling if she actually believes it herself.

When "Mulata Exportação" [Exportation Mulata] is compared to most of the poems in O Semelhante, the sublime "revolutionary" in Lucinda comes to light. A tripartite conversation between the mulata, the white master, and the judge who sits in judgment of the complaints of the mulata, "Mulata Exportação" ridicules the assumptions of the white as generous, humane, passionate, and bountiful in the treatment of the mulata. Instead, the white master is portrayed as perverse, violent, manipulative, deceitful, and a shameless figure who is only interested in violating and brutalizing the flesh of the mulata only to be disposed of as a worthless rag. The harsh and indicting voice of the mulata is heard when she invokes the memories of slavery and Senzala as opposed to the Casa Grande, and ultimately reaching the conclusion that the fact that a white man sleeps with a mulata does not imply end to racism 
nor does it absove the attrocities of the past which memories still haunt the mulata-children, attrocities committed by their own very fathers who once disowned them and now want to make love to them:

Mas que nega linda

E de olho verde ainda

Olho de veneno e açúcar!

Vem nega, vem ser minha desculpa

Vem ser meu álibi, minha bela conduta

Vem, nega exportação, vem meu pão de açúcar!

...................

Minha memória confudida, meu futebol...

Vem ser meu folclore, vem ser minha tese sobre nego malê.

Vem, nega, vem me arrasar, depois te levo pra gente sambar. ${ }^{4}$ (184)

Lucinda's treatment of "equality" in both paradigmatic poems is deceitful and non-convincing. In the former, she argues that everyone is the same. In the latter, she complains of racial discrimination. Indeed, "Mulata Exportação" is more of a caustic critique of Brazil's racial hypocrisy than a mere commentary on race relations. By juxtaposing the myth with the reality of racism especially in the angry voice of the mulata woman against the white oppressor, no further proof is required to assert that Lucinda does not believe in racial democracy. The indictment is so severe that the poetic voice ends the poem in a rage of exclamation: "Porque deixar de ser racista, meu amor, / não é comer uma mulata!” (185) [Because to cease to be racist, my love, / does not come from simply sleeping with a mulata!]. Even the assumption that "love conquers all" does not apply in Lucinda. The poems of passion suggest that race

\footnotetext{
${ }^{4}$ ["But what a beautiful black woman / And even with green eyes / Eyes of venom and sugar! / Come black woman, come be my excuse / ... / Come be my alibi, be proof of my good nature / Come, for export black woman, come my sugar loaf! /.../ My confused memory, my soccer... / Come be my folklore, come be my thesis on the Black Muslim Revolt. / Come, black woman, come to ease me, after I take you out so that we can dance samba.']
} 
has been "cleansed" as a factor and that the feeling of racelessness is mutual between the imaginary lovers that pervade Lucinda's cultural production.

That "feminine specificity is only understandable by women" sums up the cogent statements of Alice Ruiz in her preface to Lucinda's Eu Te Amo e Suas Estréias [I Love You and Their Outbreaks]. If Seigmund Freud could give up on his efforts to understand women, it is perhaps prudent to return to women for the definition of love and passion. Eu Te Amo does just that. In many instances, the expression of love, the nostalgia for love, and the search for pure love are genuine and deep. In some occasions, God is likened to love in its selflessness and sacrifice, echoing the Biblical dictum that "For God so loved the world that He gave his only begotten son" for the redemption of World's transgressions. Varied, free, and confident, the poems in $\mathrm{E} u \mathrm{Te}$ Amo exposes the woman in her most vulnerable and her most volatile. In "Da Chegada do Amor" [Of The Arrival of Love] true love is defined as that which communicates what it feels, which means what it says, which is not limited by time or space, which is tolerant of differences, which accepts the woman as she is in her different shifting moods (future, present and past), which does not engage in games of false seduction, which ejaculates and announces it, which lives a happy life without complaints, and above all, the love that loves naturally without so much effort:

Sempre quis um amor
que acontecesse
sem esforço
sem medo da inspiração
por ele acabar. (26)

Sempre quis um amor que acontecesse sem esforço por ele acabar. (26)

\author{
I always wanted love \\ that happens \\ without effort \\ without the fear of inspiration \\ that it may come to an end.
}

The title itself, "euteamo" coined from three separate words, "I love you," stems from what the poetic voice heard from her lover: "I love you helplessly." And since that day, the lover has not ceased to repeat the lovely saying. That it became the title of a series of poems on the same topic speaks to its importance in the life of Lucinda. Yet, this critic wonders if such a life based on feelings, wants, and ephemeral sentimentalities alone is not conditioned by 
shallowness and luxury. "Para Uma Saudade Gorda" [For a Fat Nostalgia], makes this point even more cogently as the poetic whines and laments her own lethargy in the face of an absent loved one:

Sofro muito a falta do meu amor: Como muito diante da televisão.

Não faço nada durmo, acordo, como, assisto, acordo, durmo, como. (120)
I suffer so much from the absence of my lover:

I eat so much in front of the television.

I do nothing

I eat, wake up, eat, watch TV, wake up, sleep, eat.

While nostalgic feelings are totally understandable, it is inconceivable that a poor woman will be indulging herself just to fill a void of an absent lover. Where there are children to feed, rent to be paid, electricity to be turned back on, water and gaz to be paid, the "luxury" of complaining about absence is non-existent. The presence of family and community fills that void and the reality of hunger. This is not to suggest that Lucinda's poetry appeals only to the elite class, but it does carry a semblance of Clarice Lispector's characters who are so comfortable that it takes an unusual event to wake to the reality of their nothingness and alienation as this poetic voice seems to discover: "I do nothing."

Yet, there is another facet of love in Eu Te Amo: the love that transcends the individual, the transnational and transcultural kind of love. In "Constatação" [Realization], the poetic voice compares herself to "her people" all over the world-a feeling that makes her feel Capeverdean, West Indian, Martinican, Jamaican, Brazilian, Bahian, American, and Senegalese all at the same time. Such feeling of love towards all races also turns into a duality of indictment and forgiveness as in "Te Perdôo" [I Forgive you] where the offensive and brutality of whites against blacks are so compeling that a symbolic sword pierces the poet's heart. Despite the the wound, hurt, and cries, the poetic voice still cries out loud in a tone of forgiveness, "I love you." Lucinda's sensitivity and sensibility are further enacted in "O Estado da Revolução" [The State of the Revolution]. This poem of solidarity with the suffering masses of Afro-Cuba paints yet another picture of Lucinda. Protesting the gallery of poverty as if living under apartheid, the poetic voice cries out her disenchantment with Cuba's pathology in the face of 
a country divided between hunger and poverty on the one hand and almighty dolar on the other: "Quero voltar pra casa. / Cuba está doente / Cuba está esquizofrênica / .../ os pretos cubanos estão sós” (95) [I want to return home. / Cuba is sick / Cuba is schizrophenic / ... / Afro-Cubans are just alone].

Although Lucinda's critique of Cuba is well taken, the same condition of squalor holds true for Afro-Brazilians — and the suggestion of returning "home" as if home is a better place, is misleading. Of course, the "home" Lucinda is referring to is that of the affluent which defines her own world. Nonetheless, through her "poetry as show business" Lucinda is mediating the world of the favela (slum) which she hardly talks about, with the world of the rich which she seems to be addressing. Responding to the criticism that his poetry is "abstruse," Lucinda defends herself by stating that she will not limit herself to censorship or the ghetto mentality which she finds "improductive and sterile." Rather, she prefers what she calls a "mixture of thought, a mixture of culture." While Lucinda's shows are electrifying, I personally think she needs to reach out more to the community instead of select audiences that further alienate her from her own Afro-Brazilian roots which she never lays claim to. She is sadly in the contemporary group of racial democracy proponents like Jorge Amado, Gilberto Gil, and Caetano Veloso.

\section{Self-Regenerative Female Discourse}

Sharply contrasting the experience of Elisa Lucinda, two Afro-Mineiran voices, Conceição Evaristo and Jussara Santos, address issues faced by Afro-Brazilians in general, and Afro-Brazilian women in particular. Like Agua Viva or Laços de Família [Family Ties] and in fact, other Lispectorian works and characters, Conceição Evaristo's Ponciá Vicentio sets a new record in Afro-Brazilian creative imagination. Afterall, the mysterious inheritance that Grandfather Vicêncio left for the protagonist is the "Found Memories" now recuperated through tortuous lingustic journey, aided by the refreshing waves and suppleness of the waters of the river which give solace to a wandering soul in search of meaning of the meaninglessness of life. Through a powerful poetic invocation of places and people, memories of family 
members lost and found, through encounters, departures, and searches for reencounters, through sustained suspense and continued agitations about the past-present-future, Ponciá Vicentio enriches the human mind and provides hope in the face of hopelessness. The narrative style is remarkably emotive and philosophical_-providing a stage where all actors seem not to understand each other and those who do know each other cannot communicate what they know except in codes and gestures. A frustrating theater of the absurd, only an attentive reader can piece together the puzzle as each chapter is an enactment of magic, frustration, violence, hope, brutality, creativity, goodwill, and a desire to "shorten one's life" in a desperate search for meaning in a life so devoid of meaning. Evaristo's ability to tell such a pessimistic story with an optimistic ending strikes a delicate balance between the poetic and the personal. While it is not clear if there is any autobiographical connections in this powerful piece, the consciousness of the poet is written all over the text. It is a text that has the potential to take reader back to their past in order to relive even memories they have easily supressed due to the passage of time. Each character is unique and compelling: Grandfather Vicêncio and his desfigured hand, Ponciás father, who is weak as opposed to her mother who is strong and domineering, Luandi and his quest to become a soldier in order to feel powerful, Soldado Nestor and his compelling image of the "powerful" and graceful Afro-Brazilian, the mysterious, old, and wise Nêngua Kianda who speaks in parables, and Ponciá Vicêncio and her strange world which is only understandable to her alone and not even to her "husband."

Underlying this beautifully crafted story within a story is a sense of magic and resistance through which Afro-Brazilians survived slavery and oppression. In addition to the story of Ponciá Vicêncio, the reader is also invited to the world of Afro-Brazilians. There are many moments in the text when the protagonist revisits the butalities of slavery and the superficial resistance of Afro-Brazilians even after abolition. A striking instance had to do with how men were treated at the hands of their bosses who simply treated them as “objects." In recuperating her vague memories of her father, Ponciá Vicêncio recounts a disturbing episode where as a plaything of the young white Master, he was ordered to open his mouth for the youngster to urinate and he accepted this as part of what was expected of him: 
Era pajem do sinhô-moço. Tinha a obrigação de brincar com ele. Era o cavalo onde o mocinho galopava sonhando conhecer todas as terras do pai. Tinham a mesma idade. Um dia o coronelzinho exigiu que ele abrisse a boca, pois queria mijar dentro. O pajem abriu. A urina do outro caía escorrendo quente por sua goela e pelo canto de sua boca. Sinhô-moço ria, ria. Ele chorava e não sabia o que mais lhe salgava a boca, se o gosto da urina ou se o sabor de suas lágrimas..$^{5}(14)$

Such a bleak and offensive memory of one's father naturally brings a sense of bitterness, shame, and perhaps more appropriately, hate. The protagonist pondered a series of questions: if blacks were free, why were they still obliged to serve the "masters"? Why could the "freed slaves" not leave in search of better lives and settlements. She thought of asking her father but was afraid of his response in the midst of dealing with his own shame, honor, and anger.

The text cannot be understood as a set of themes but an organic system of experiences by characters who individually and collectively complete each other while representing a microcosm of a larger society. Each individual actually fills the void of the other without filling it. Grandfather Vicêncio is the fundamental mystery whose name is taken from his former slave owner. Both sad and smiling, he represents the classic ambivalent figure who can neither articulate his state of mind nor do something to change it. Instead, he masks his feelings in a crying-laughing appearance. The lack of his own identity translates into lack of identity for the rest of the family. If there is any common character among them, it lies somewhere between family ties and the necessity to complete their own individual "story" and put an end to a suspended life. Father Vicêncio's own personal weakness, his "femininized" st"atus in the household further weakens any sense of father-figure since his world revolves around his work in the "lands of the whites" where he is obliged to make a living as a worker-servant. His vacation days are far from being restful as he is equally onliged to "serve" another "master,"

\footnotetext{
5 “'He was the Master Jr.'s babysitter. He had the responsibility to play with him. He was the play-horse on which the young one galloped dreaming of knowing all the lands belonging to his father. They were of the same age. One day, the young Colonel ordered him to open his mouth so that he could urinate within. The babysitter opened it. The urine of the other warmly flowed through his throat and mouth. Master Jr. laughed and laughed. He cried and no longer knew what was so salty in his mouth: the urine or the flavor of his tears."
} 
his own wife. The subversion of the patriarchal model is fascinating and ellicits delight from the protagonist: "O pai era forte, o irmão quase um homem, a mãe mandava e eles obedeciam. Era tão bom ser mulher!” (24) [Father was strong, brother was becoming a man, mother gave orders and they obeyed. It was so nice to be a woman!]. Taken as a deeper statement about the empowered condition of women, one would expect the protagonist to adopt this model in her own life. Instead, the events of her life suggest that she is suffering from some inexplicable sense of absence from herself and the world: she would be beaten by men in her life, she would lose all her seven children shortly after birth to the extent that she became insecure as a woman, depending on every man to help fulfill her life as woman. By the time she finishes telling her story, she has matured philosophically to the extent of questioning the rationale of bringing a child into this hopeless world to suffer:

Valeria a pena pôr um filho no mundo? Lembrava-se de sua infância pobre, muito pobre na roça e temia a repetição de uma mesma vida vida para os seus filhos. (...) Os pais, os avôs, os bisavôs sempre trabalhando nas terras dos senhores. A cana, o café, toda a lavoura, o gado, as terras, tudo tinha dono, os brancos. Os negros eram donos da miséria, da fome, do sofrimento, da revolta suicida. (...) A vida escrava continuava até os dias de hoje. Sim, ela era escrava também. ${ }^{6}(84)$

Although many events of her life make her appear to be insane, Ponciá Vicêncio is quite sane. Her alienation in the city after leaving the country must be seen as necessary adjustment just like her varied experience of violence and violation in the hands of men must be read as her own rite of passage from innocence to experience.

When seen as the alter-ego of the author, Ponciá Vicêncio is an omniscient and extremely lucid character. Despite the psychological trauma she experienced after leaving her familiar

\footnotetext{
6 "Would it be worth bringing a child into the world? She remembered her own poor childhood, very poor in the country and was afraid of the repetition of the same life for her children. (...) The parents, grandparents, great grandparents always worked on the lands of the masters. Sugar cane, coffee, farming, livestock, lands, all belonged to white owners. Blacks only owned misery, hunger, suffering, suicidal rebellion. (...) Slave life continued until this day. Yes, she was a slave as well."
} 
landscape, she quickly adapted to the realities of deception as well as the competitiveness demanded by city life. Yet, she was never totally displaced from her roots. The emptiness that surrounds her life turns out to be the sense of gulf every person searching for meaning feels when they do not find a way or when they do not succeed. Success eventually comes through her persistence and determination especially the journeys (back and forth to tge coubtry) in search of her family. While the scenes of reencounter first between Maria Vicêncio (mother) and brother, and then between mother and daughter may appear simplistic and expected, the sophistication lies in the "missing link" provided by both Soldado Nestor, a source of pride for Ponciá Vicêncio, and Nêngua Kianda, a source of comfort and wisdom for mother, brother, and sister in moments of confusion and desperation. Her ability to portray each individual as a human being and not judge them is a rare gift. Instead of being judgmental, she represents members of her family as victims of a society that has conditioned and failed them and yet faults them for not being able to withstand the pressure. Ponciá Vicencio is a story of the regeneration of the human spirit under unimaginable circumstances. It cogently theorizes on life as a stream where different currents meet in order to refresh and redirect their paths. It is also a testimony to the survival ethos of Afro-Brazilians vividly captured in the creative imagination and political accomplishment of Conceição Evaristo.

Jussara Santos's de flores artificiais complements Evaristo's genial effort in the sense that this collection of short stories launches another Afro-Brazilian female voice who needs to be heard in the midst of negative critical commentary that has reduced Afro-Brazilian writing to "anti-establishment rhetoric" "non-aesthetic rigor," and "marginality." If with Ponciá Vicêncio Evaristo successfully proves that Afro-Brazilian women can write excellent pieces of literature whether in verse or in prose, Santos's de flores artificiais confirms that Afro-Brazilian women writing has moved beyond the shadow of their male counterparts and is now poised for a new beginning. Like the voices of Miriam Alves, Esmeralda Ribeiro, Sônia Fátima da Conceição, and Conceição Evaristo among others, Santos's de flores artificiais revisits the concerns of AfroBrazilian women as they grapple with issues of human nature, confusion, love, racial discrimination, and other alienating states of mind. In structure, the stories are mostly 
reflective, fragmented, and cerebral, often making the reader wonder if this is intentional or just a matter of style. When compared to Conceição Evaristo, there is a wide gap of imagination, finesse, and tenderness. Evaristo's style is less reflective yet poetic, less demanding in terms of making sense of words that are scattered all over the pages as if wanting to tell these stories without telling them, while Santos's narratives are not intended to be rational in the linear sense. As short stories, they are also limietd by space and a single problematic. In "Sem Título" [Without Title] which opens the collection, the narrator reflects on a mundane event such as her dog gasping for air and upon rushing close to see what was the matter, realizes that a neighbor had given the dog a piece of meat with a hidden plastic ball which ended up choking the dog. While still wondering who could be the culprit of this wicked act, the narrative shifts suddenly to the grandmother who is perspiring from painstakingly washing her clothes. The connection is far-fetched but can only be an epiphanic device if intended to be an analogy between the choking dog and the breathless old woman. While the remaining stories are less fragmented and disjointed in the Lispectorian sense, they share a commonality of magical suspension of disbelief.

The sense of disbelief looms large in "A Vez da Caça" [Time of the Prey] where a strange "hunting" expedition of children via the Internet turns vindictive as the supposedly "dead" or "killed" children return as a group to torment their killers, Mário and Glória. Their efforts to resist the ghostly children remain abortive until Mário leads the plea for clemency which fell on deaf ears. Glória vows never to be involved in such a game leaving Mário to deal with his self-provoked "demons" and nightmares by himself:

Mário nu diante do computador não conseguia mais escrever. Os olhos do menino não saíam de sua cabeça. Fizesse o que fizesse os olhos dele estavam lá a persegui-lo. Depois da noite anterior, Mário sabia que fora caçado, sabia que não mais escreveria e que não mais caçaria. ${ }^{7}(24)$

${ }^{7}$ Naked before the computer, Mário was no longer able to write. The eyes of the boy were glued to his head. Whatever he did, the eyes were there to persecute him. After the previous night, Mário knew that other being a prey himself, he would no longer write nor would he hunt again. 
Even if this narrative is perceived as an allegory that ridicules any form of injustice against children, and articulates the moral of good overcoming evil, the construction of the story is at best artificial or deliberately fantastic. If the entire narrative is structured in the "surrealistic" mode within the space of the computer, the moral of the story becomes multiple for it can also be understood that the computer is the "root" of all evil including the fantasy of hunting and killing children as a kind of game. Other than the passing mention of racial discrimination in the story, "Sob as Asas de Seda Azul do Sr. Smith" [Under the Cotton Wings of Mr. Smith] which also epigraphs Toni Morrison's Song of Solomon, the entire collection may be said to be masked in the rhetoric of social justice. Overall, the social message of the "suicidal flight" of the oppressor, the retribution received by the hunters of children, and the unspoken indictment of the cruel kindness to an innocent dog, all conspire to identify Jussara Santos as a welcome new Afro-Brazilian voice whose preoccupations transcend gender but aspire towards equality and tenderness in all humans.

The search for the "universal" without losing the "local" is what unites the six cultural producers examined in this chapter. The previous chapter on "modernist" impulses sets the tone for the appreciation of what we termed "Quilombo without borders" in the sense that these cultural producers are no longer operating in a fixed location and the meaning of a "quilombo" is now relative to the ideological orientation and disposition of the individual.

In returning to Linda Huntcheon's notion of the problematic "postmodern" figure, it is informative to see a duality of tendencies some of the writers examined. All may actually be said to be simultaneously "compromised and oppositional" at the same time but in varying degrees - an ample proof of their conditioned site of cultural production and their necessity to negotiate through the dictatorship of production and articulation. For Paulo Colina, samba like sex or carnaval is that moment that unifies all races within an ephemeral state of tolerance and ambivalence. Salgado Maranhão does not want to be the "poet of the people" but a poet 
free from any schools of thought that hinder his deeper engagement with form. In this sense, she shares a trait with Elisa Lucinda whose focus is transforming declamation of poetry into a performance and show business. As for Márcio Barbosa and Conceição Evaristo, "quilombo" is a first love, a fortifying and necessary muse of inspiration. Both vent their frustrations without any pretexts about the miserable conditions in which Afro-Brazilians languish. While Jussara Santos may be the least compelling and one that is "searching" for her own voice of comfort and mission, she nonetheless represents a post-modernist voice on her way to affirmation and consolidation.

\section{DISCURSOS REGENERATIVOS EM ESCRITORES CONTEMPORÂNEOS DE MULHERES AFRO-BRASILEIRAS}

RESUMO: Com base na ideia de James Scott de "transcrições ocultas" em Domination and the Arts of Resistance, este estudo teoriza sobre os sites discursivos hipotéticos progressistas como movendo-se do continuum do senhor escravagista duro para o site do negro livre entre amigos e familiares. Em vez do medo da articulação ou da necessidade de mascarar que opera no quadro da transcrição pública, a moldura alternada da transcrição oculta sugere um medo menos explícito de articulação diante da opressão. Além de destacar trabalhos recentes sobre questões de gênero, identidade e cidadania no Brasil, este ensaio argumenta que uma nova onda de discursos regenerativos está surgindo entre as escritoras afro-brasileiras, ainda que poucas e distantes entre si. Essas obras demonstram atos regenerativos conscientes do ponto de vista da rejeição da vitimização.

PALAVRAS-CHAVE: Escritoras afro-brasileiras; Transcrições ocultas; Resistência.

\section{BIBLIOGRAPHY}

AFOLABI, Niyi. Afro-Brazilians: Cultural Production in a Racial Democracy. Rochester, NY: University of Rochester Press, 2009.

. "Beyond the Curtains: Unveiling Afro-Brazilian Women Writers." Research in

African Literatures 32.4 (2001): 117-135.

ALVES, Miriam. Momentos de Busca. São Paulo: Self-Edition, 1983.

. Estrelas no dedo. São Paulo: Self-Publication, 1985. 
Terramara. (co-authored with Cuti and Arnaldo Xavier). São Paulo: SelfPublication, 1988.

ALVES, Miriam; CAROLYN Richards Durnham. Eds. Enfim Nós/Finally Us: Contemporary Black Women Writers. Colorado Springs: Three Continents, 1995.

ALVES, Miriam. “Aro Boboi.” Unpublished long poem under review with Mazza Edições, Belo Horizonte, Minas Gerais-Brazil (2003).

ANDRADE, Inaldete Pinheiro de. Pai Adão Era Nagô. Recife: Produção Alternativa, 1989. AUGEL, Moema Parente. “A Imagem da África na Poesia Afro-Brasileira Contemporânea." Afro-Ásia 19-20 (1997): 183-199.

BARBOSA, Maria José Somerlate. "Strategies of Poetic Language in Afro-Mineiro Discourses." Luso-Brazilian Review 37.1 (2000): 63-82.

. "The Consciousness of Femininity and Black Consciousness in Brazilian

Literature." Journal of Afro-Latin American Studies and Literatures 1.1 (1993-94): 25-31.

BRITO, Edalvado. "Uma Ode aos Valores Culturais da Raça Negra." A Mulher de Aleduma. Aline França. Salvador: Ianamá, 1985. 7-8.

BRITO, Maria da Conceição Evaristo de. "Literatura Negra: Uma Poética de Nossa AfroBrasilidade.” Unpublished Masters Thesis, Pontífica Universidade Católica do Rio de Janeiro, Brazil, 1996. 152pp.

COLINA, Paulo. Plano de Vôo. São Paulo, Roswitha Kempf Editores, 1984. - A Noite Não Pede Licença. São Paulo, Roswitha Kempf Editores, 1987. - Todo o Fogo da Luta. São Paulo: João Scortecci Editora, 1989.

DUKE, Dawn. Literary Passion, Ideological Commitment: Toward a Legacy of Afro-Cuban and Afro-Brazilian Women Writers. Lewisburg: Bucknell University Press, 2008.

DURHAM, Carolyn Richardson. "The Beat of a Different Drum: Resistance in Contemporary Poetry by Afro-Brazilian Women.” Afro-Hispanic Review 14.2 (1995): 21-26.

. "Space and Time: Afro-Brazilian History in the Poetry of Miriam Alves." CLA Journal 16.2 (1997): 185-196.

. “Art for Life's Sake: Literature by Esmeralda Ribeiro, Sônia Fátima da Conceição and Miriam Alves." Palara 1 (1997): 36-42.

EVARISTO, Conceição. Ponciá Vicêncio. Belo Horizonte: Mazza Edições, 2003.

FERACHO, Lesley. "Transgressive Acts: Race, Gender and Class in The Poetry of Carolina Maria de Jesus and Miriam Alves." Afro-Hispanic Review 18.1 (1999): 38-45.

FRANÇA, Aline. Negão Dony. Salvador: Prefeitura de Salvador, 1979. 
- A Mulher de Aleduma. Salvador: Clarindo Silva, 1981.

. Os Estandartes. Rio de Janeiro: Littera, 1993.

. "As Fontes de Salvador e seus Convidados." Unpublished play, premiered in

Salvador in 1998. 21pp.

GATES JR., Henry Louis. The Signifying Monkey: A Theory of African-American Literary Criticism. New York: Oxford, 1988.

GILROY, Paul. The Black Atlantic: Modernity and Double Consciousness. Cambridge: Harvard University Press, 1993.

GOOD, James and Irving Velody. The Politics of Postmodernity. Cambridge: Cambridge University Press, 1998.

GUIMARÃES, Geni. Terceiro filho. São Paulo: Jalovi, 1979.

. Da flor o afeto, da pedra o protesto. São Paulo: Self-Publication, 1981.

. Balé das emoções. Barra Bonita/São Paulo: Evergraf, 1985.

. Leite do Peito. Belo Horizonte: Mazza, 2001.

HOMERO, Rita. "Elisa Lucinda Abre o Verso." Raça 2.10 (1997): 46-49.

HUNTCHEON, Linda. The Politics of Postmodernity. New York: Routledge, 2002.

LUCINDA, Elisa. O Semelhante. Rio de Janeiro: Record, 1994.

. Eu te amo e suas estréias. Rio de Janeiro: Record, 1999.

. Contos de vista. São Paulo: Global Editora, 2004.

- Canto à Negra Mulher Amada. São Paulo: Self-Publication, 1986

RIBEIRO, Esmeralda. Malungos e Milongas. São Paulo: Self-Publication, 1988.

. “Ogun.” Callaloo 18.4 (1995): 913-919.

SANTOS, Jussara. "Afrodicções: Identidade e Alteridade na Construção Poética de Três Escritores Negros Brasileiros.” Unpublished Masters Thesis, Pontifífica Universidade Católica de Minas Gerais, 1998. 119pp.

. De Flores Artificiais. Belo Horizonte: Sobá / O Meio, 2000.

SCOTT, James. Domination and the Arts of Resistance. New Haven: Yale University Press, 1990 .

Recebido em: 16/08/2018.

Aprovado em: 04/02/2019. 